\title{
Pengaruh Empat Variabel Terhadap Kualitas Hidup Lansia Penderita Diabetes Melitus Tipe II
}

\author{
Saiful Gunardi, ${ }^{1}$ Catur Septiawan ${ }^{2}$ \\ ${ }^{1,2}$ Program Studi Magister Kesehatan Masyarakat \\ Sekolah Tinggi Ilmu Kesehatan Indonesia Maju \\ Jln. Harapan Nomor 50, Lenteng Agung - Jakarta Selatan 12610 \\ Telp: (021) 78894045 Email: ${ }^{1}$ saiful.gunardi@gmail.com, ${ }^{2}$ uima.penjaminmutu@gmail.com
}

\begin{abstract}
Abstrak
Angka kejadian PTM yaitu kondisi DM lebih tinggi pada lansia dari pada usia muda, dimana Indonesia menempati urutan ketujuh di dunia dan sudah menjadi penyakit pembunuh nomor tiga dan diperkirakan sekitar 20\% lansia mengalami DM, dan sebagian besar lansia tidak menyadari adanya penyakit DM tersebut, yang berdampak dapat menurunkan kualitas hidup lansia.Tujuan penelitian ini untuk mengetahui pengaruh langsung atau tidak langsung pengaruh peran petugas kesehatan, fungsi keluarga, motivasi diri, gaya hidup terhadap kualitas hidup lansia penderita DM tipe 2 di wilayah Puskesmas Ciracas. Metode penelitian kuantitatif dengan desain cross-sectional. Jumlah sampel 94 penderita diabetes melitus. Metode analisis dengan Structural Equation Model (SEM) mengunakan SmartPLS 2.0. Hasil penelitian menghasilkan temuan bahwa kualitas hidup lansia penderita DM tipe 2 dipengaruhi oleh peran petugas kesehatan $(9,33 \%)$, fungsi keluarga $(35,97 \%)$, motivasi diri $(16,47 \%)$ dan gaya hidup $(26,43 \%)$. Total besaran pengaruh langsung terhadap kualitas hidup lansia penderita DM tipe 2 sebesar 88,21\% dan pengaruh tidak langsung sebesar 3,48\%. Fungsi keluarga dan gaya hidup merupakan faktor yang dominan mempengaruhi kualitas hidup lansia penderita diabetes mellitus. Model hasil analisis dapat menjelaskan $(99,97 \%)$ keragaman data dan mampu mengkaji fenomena yang dipakai dalam penelitian, sedangkan $(0,03 \%)$ dijelaskan komponen lain yang tidak ada dalam penelitian ini. Saran penelitian adalah petugas kesehatan meningkatkan perannya untuk meningkatkan kualitas hidup lansia pada penderita DM tipe 2.
\end{abstract}

Kata Kunci : Kualitas Hidup Lansia, Fungsi Keluarga, Gaya Hidup, Motivasi Diri, Peran Petugas Kesehatan

\begin{abstract}
The incidence of PTM is that the condition of DM is higher in the elderly than in young age, where Indonesia ranks seventh in the world and has become the third killer disease and it is estimated that about $20 \%$ of elderly have DM, and most elderly are not aware of this diseas, the impact can decrease quality of life of elderly. The purpose of this study was to determine the effect of the direct or indirect influence of the role of health care workers, family functioning, self-motivation, lifestyle of the quality of life of elderly patients with DM type 2 in Puskesmas Ciracas. This research method was quantitative approach by cross-sectional design. Total sample was as 94 patients with DM. The method of analysis was Structural Equation Model (SEM) using SmartPLS 2.0. The test results of this research findings variables quality of life of elderly patients with DM type 2 is influenced by the role of health workers (9.33\%), family functioning (35.97\%), self-motivation (16.47\%) and lifestyle (26.43\%). The total amount of direct influence on the quality of life of elderly patients with DM type 2 as $88.21 \%$ and the indirect effect as 3.48\%. A family function and lifestyle is the dominant factor affecting the quality of life of elderly patients with DM. Model analysis results can be explained as $99.97 \%$ diversity data and capable of studying the phenomenon of the used in the study, whereas as $0.03 \%$ described another component that does not exist in this study. Suggestion research health personal should increase the role to increase the quality of life of the elderly in patients with DM type 2.
\end{abstract}

Keywords : : Quality of Life of Elderly, Family Function, Lifestyle, Personal Motivation, Role of Health Personnel 


\section{Pendahuluan}

Struktur ageing population merupakan cerminan dari semakin tingginya rata-rata Usia Harapan Hidup (UHH) penduduk Indonesia. Tingginya UHH merupakan salah satu indikator keberhasilan pencapaian pembangunan nasional terutama di bidang kesehatan. Hasil proyeksi penduduk 2010-2035, Indonesia akan memasuki periode lansia (ageing), dimana 10\% penduduk akan berusia 60 tahun ke atas, di tahun $2020{ }^{1}$

Dengan bertambahnya umur, fungsi fisiologis mengalami penurunan akibat proses penuaan sehingga penyakit tidak menular banyak muncul pada lanjut usia. Selain itu masalah degeneratif menurunkan daya tahan tubuh sehingga rentan terkena infeksi penyakit menular. Hasil Riskesdas 2013, penyakit terbanyak pada lanjut usia adalah Penyakit Tidak Menular (PTM) antara lain hipertensi, artritis, stroke, Penyakit Paru Obstruktif Kronik (PPOK) dan Diabetes Mellitus (DM), dimana prevalensi masalah kesehatan DM pada lansia dengan usia 65 - 74 tahun sebesar $4,8 \%{ }^{2}$

Hasil laporan statistik International Diabetic Federation (IDF) menyatakan bahwa terdapat 3,2 juta kasus kematian akibat penyakit diabetes mellitus tipe 2 setiap tahun. ${ }^{3}$ WHO menyatakan jumlah orang dewasa yang terserang diabetes telah hampir empat kali lipat di seluruh dunia sejak 1980 menjadi 422 juta, terutama di negara berkembang. ${ }^{4}$ Data International Diabetic Federation (IDF) 2015 menyebutkan jumlah penderita diabetes sebanyak 415 juta dan diperkirakan akan terus meningkat pada tahun 2040 sekitar 642 juta (55\%). Sedangkan di Indonesia menempati urutan ketujuh sebagai penderita terbesar di dunia, jumlah penderita Diabetes Melitus di Indonesia diperkirakan 10 juta orang. ${ }^{5}$ Diabetes Melitus diungkapkan oleh Sample Regisration Survey 2014 di Indonesia sudah menjadi penyakit pembunuh nomor tiga. ${ }^{6}$

Kondisi kesehatan/status disabilitas penduduk dipengaruhi oleh faktor perorangan dan faktor lingkungan. Konsep ini memberikan pandangan yang lebih komprehensif, bahwa kedua faktor tersebut tidak dapat dipisahkan satu sama lainnya dalam mempengaruhi kualitas hidup seseorang atau sekelompok orang. Berdasarkan hasil penelitian penduduk yang tidak menderita penyakit tidak menular hampir 1,5 kali mempunyai kualitas hidup baik
(79,0\%) dibandingkan dengan penduduk yang menderita penyakit tidak menular $(49,4 \%)$ dan penduduk dengan kelompok umur lebih dari 64 tahun berisiko 5 kali memiliki kualitas hidup kurang dibandingkan kelompok umur 64 tahun atau kurang, penduduk menderita penyakit tidak menular berisiko 2,6 kali dibandingkan dengan yang tidak menderita penyakit tidak menular. ${ }^{7}$ Bila melihat hasil penelitian tersebut maka lansia dengan diabetes mellitus pun kemungkinan akan memiliki resiko memiliki kualitas hidup yang kurang.

Kualitas hidup lansia tidak dapat terlepas dari banyak faktor antara lain yaitu keluarga. Dukungan keluarga dapat meliputi dukungan emosional, dukungan penghargaan, dukungan informasi dan dukungan instrumental. Penelitian tentang hubungan fungsi keluarga dengan kualitas hidup lansia menunjukan hasil bahwa lansia yang berasal dari keluarga dengan fungsi keluarga sehat memiliki kemungkinan untuk berkualitas hidup baik 25 kali lebih besar daripada lansia dengan fungsi keluarga tidak sehat dan terdapat hubungan yang signifikan antara fungsi keluarga dengan kualitas hidup pada lansia $(\mathrm{OR}=24,45 ; \mathrm{p}=0,040 ; \mathrm{CI} 95 \% \quad 1,16$ hingga 533,04$){ }^{8}$

Faktor lain yang dapat mempengaruhi kualitas hidup lansia adalah gaya hidup. Gaya hidup merupakan suatu cara atau metode bertindak atau berpenampilan yang diatur oleh standar kesehatan tertentu. Standar kesehatan ini meliputi makan dan minum, kerja (termasuk belajar) dan istirahat, olahraga atau latihan, hubungan sosial, keseimbangan emosi atau mental, spiritual, okupasional dan sesuai dengan norma-norma sosial budaya daerah atau nasional. ${ }^{9}$ Penelitian terkait hubungan gaya hidup dengan kualitas hidup lansia telah dilakukan di Iran, menunjukan hasil kualitas hidup dan gaya hidup memiliki hubungan signifikan secara statistik dengan usia, jenis kelamin, tingkat pendidikan, status perkawinan, status pensiun, memiliki pekerjaan, sumber pendapatan, masalah pencernaan, depresi, nyeri sendi, osteoporosis, hipertensi, jatuh dan gangguan tidur. Ada juga hubungan langsung antara gaya hidup dan kualitas hidup. ${ }^{10}$

Faktor lain yang dapat mempengaruhi kualitas hidup lansia adalah motivasi diri. Hasil penelitian menunjukkan bahwa kelompok yang paling ditentukan 
sendiri melaporkan nilai lebih tinggi secara signifikan dalam empat domain dari HRQOL, yaitu keterbatasan peran karena kesehatan fisik, nyeri tubuh, fungsi sosial dan keterbatasan peran karena kesehatan emosional $(\mathrm{p}=0,01)$. Data ini menunjukkan pentingnya mempertimbangkan perspektif motivasi dan pemeliharaan olahraga di kalangan orang dewasa yang lebih tua sebagai tantangan kesehatan masyarakat yang penting. ${ }^{11}$

Kualitas hidup lansia juga tidak bisa terlepas dari peran petugas kesehatan. Peran petugas kesehatan meliputi peran sebagai scenner, komunikator, motivator, konselor, dan fasilitator. ${ }^{12}$ Penelitian yang terkait menunjukan hasil peran pendampingan spiritual berhubungan dengan motivasi kesembuhan pada pasien lanjut usia di Instalasi Rawat Inap Dewasa Rumah Sakit Baptis Kediri. Motivasi pasien lansia yang kuat untuk sembuh akan mendukung asuhan keperawatan yang diberikan, sehingga upaya penyembuhan atau peningkatan kesehatan pasien akan lebih mudah dicapai. Peran pendampingan spiritual sebenarnya merupakan kompetensi dari profesi keperawatan. Peran perawat dalam memberikan asuhan keperawatan pada pasien secara holistik meliputi biologi, psikologis dan spiritual. $^{13}$

Berdasarkan studi pendahuluan di Puskesmas Kecamatan Ciracas Jakarta Timur diperoleh data penderita DM tipe 2 sebanyak 101 orang. Berdasarkan hasil wawancara peneliti menemukan data bahwa ditemukan satu lansia dengan diabetes mellitus yang harus diamputasi, karena kurang pengetahuan terkait penyakitnya, selain itu terdapat 9,9\% lansia mengeluh tentang kehidupannya di masa tua yang sangat susah, merasa terbatas aktivitasnya, sering sakit-sakitan, lingkungan kurang bersahabat, dan kurang percaya diri dengan penampilan fisiknya sekarang, hal ini menunjukan tanda rendahnya kualitas hidup yang dimiliki oleh lansia. Untuk perbandingan besarnya jumlah lansia penderita DM tipe 2 di daerah lain seperti di Puskesmas Rangkapan Jaya Baru kecamatan Pancoran Mas Depok pada bulan Januari 2017 berjumlah 28 orang. Dengan demikian perbandingan jumlah lansia penderita DM tipe 2 di wilayah Puskesmas Ciracas lebih besar dibandingkan daerah lain. Berdasarkan paparan di atas maka peneliti ingin mengetahui Pengaruh Peran Petugas Kesehatan, Fungsi Keluarga, Motivasi Diri dan Gaya Hidup Terhadap Kualitas Hidup Lansia Penderita DM tipe 2.
Tujuan penelitian ini untuk mengetahui pengaruh langsung atau tidak langsung pengaruh peran petugas kesehatan, fungsi keluarga, motivasi diri, gaya hidup, terhadap kualitas hidup lansia penderita DM tipe 2.

\section{Metode}

Metode penelitian ini kuantitatif dengan desain cross sectional yang gunanya untuk menganalisis hubungan kausal antara variabel-variabel melalui pengujian hipotesis yaitu untuk menganalisis pengaruh langsung dan tidak langsung serta besarannya antara peran petugas kesehatan, fungsi keluarga, motivasi diri, gaya hidup terhadap kualitas hidup lansia penderita DM tipe 2. Lokasi Penelitian ini dilakukan di Wilayah Puskesmas Ciracas Jakarta Timur. Adapun waktu penelitian ini dilakukan pada bulan Januari Februari 2017.

Populasi dalam penelitian ini adalah lansia penderita DM tipe 2 yang berjumlah 101 orang, sedangkan teknik pengambilan sampel dengan menggunakan purposive sampling, yaitu pengambilan sampel berdasarkan kriteria. Kriteria inklusi yaitu lansia penderita Diabetes Melitus tipe 2 di wilayah Puskesmas Ciracas yang aktif berkunjung ke Puskesmas. Kriteria eksklusi dalam penelitian ini adalah lansia penderita DM tipe 2 di wilayah Puskesmas Ciracas yang menolak ikut serta dalam penelitian.

Jumlah sampel yang diambil sesuai dengan kaidah jumlah sampel pada pedoman PLS (Partial Least Squares) dengan rumusan, dimana besaran sampel (Sample size) yang diambil adalah 5 hingga 10 kelipatan dari jumlah indikator yang akan diteliti. ${ }^{14}$ Sehingga dalam hal ini besaran sampel yang diambil adalah berkisar 75 hingga 150 yaitu sebesar 94 responden.

Instrumen penelitian ini menggunakan kuisioner yang dibuat dari masing- masing variabel. Variabel kualitas hidup lansia berjumlah 24 soal, sedangkan variabel yang lain yaitu peran petugas kesehatan, motivasi diri, fungsi keluarga dan gaya hidup masingmasing berjumlah 15 butir soal, sehingga keseluruhan instrumen penelitian ini berjumlah 84 butir soal. Untuk menjaga agar kuisioner valid dan reliable maka kuisioner tersebut diuji dengan menggunakan Structural Equation Model (SEM). 
Pengolahan data penelitian ini menggunakan SPSS 18 untuk mengolah statistik deskriptif. Sedangkan untuk mengetahui pengaruh antar variable menggunakan SmartPLS 2.0. Pengolahan data dilakukan dengan editing, coding, processing, cleaning dan transforming.

Metode analisis data yang digunakan dalam penelitian ini adalah analisis univariat, analisa bivariat dan multivariat. Analisis univariat dilakukan untuk satu variabel atau per variabel. Variabel-variabel yang digambarkan secara tunggal dalam independen yaitu (peran petugas kesehatan, fungsi keluarga, gaya hidup dan motivasi diri), sedangkan variabel dependennya yaitu (kualitas hidup lansia). Analisis bivariat menggunakan uji chi square. Uji chi square dalam penelitian ini digunakan untuk melihat variasi total jawaban responden per variabel terhadap karakteristik responden penelitian. Karakteristik responden dalam penelitian ini antara lain: umur, pendidikan, jenis kelamin dan status perkawinan. Nilai chi square signifikan bila $\mathrm{P}$ value kurang dari 0,05 , dengan $\alpha=5 \%{ }^{14}$

Analisis penelitian ini digunakan untuk mengetahui ada tidaknya pengaruh peran petugas kesehatan, fungsi keluarga, motivasi diri dan gaya hidup terhadap kualitas hidup lansia penderita DM tipe 2. Sedangkan analisa multivariat penelitian ini digunakan untuk pengujian hipotesis yang akan dilakukan dengan menggunakan SEM. Alasan menggunakan alat analisis ini dikarenakan adanya beberapa hubungan yang komplek dari beberapa variabel yang diuji dalam penelitian ini, sehingga penggunaan teknik multivariat yang lainnya tidak memadai untuk digunakan.

Penyajian data frekuensi responden dari sampel penelitian disajikan berupa gambaran atau deskripsi mengenai sampel, dimana penjelasan juga disertai ringkasan berupa tabel dari deskripsi yang utama. Hal ini dilakukan untuk membantu pembaca lebih mengenal karakteristik dari respondan dimana data penelitian tersebut diperoleh. Penyajian analisa SEM dari pengolahan data output menggunakan bantuan SmartPLS 2.0, disajikan dalam diagram dan tabel. Penyajian tabel outer model terdiri dari :

\section{a. Cross loading (discriminant validity)}

Nilai Cross loading (discriminant validity) dapat mengevaluasi validitas terhadap indikator. Suatu indikator reflektif dapat dinyatakan valid jika mempunyai loading factor diatas 0,5 terhadap konstruk yang dituju berdasarkan pada substantive content-nya dengan melihat signifikansi dari weight $(\mathrm{t}=$ 1,96). ${ }^{15}$

b. Square root of avarage variance extracted ( $A V E)$

AVE cara lain yang digunakan untuk menguji discriminant validity, variabel dapat dinyatakan valid bila nilai AVE diatas $0,5 .{ }^{15}$

c. Cronbach's Alpha dan Composite
reliability

Nilai Cronbach's Alpha dan Composite reliability diatas 0,70 menunjukkan bahwa semua variabel dinyatakan reliable. ${ }^{15}$

Penyajian tabel inner model terdiri dari :

a. Nilai R-Square

$R$-Square merupakan Uji Goodness-fit model dengan cara melakukan uji inner model terhadap model structural. ${ }^{15}$

b. Nilai T-Statistic

Nilai T-Statistic merefleksikan terhadap variabel signifikan bila $>1,96 .{ }^{15}$

c. Uji Hipotesis

Uji hipotesis dapat dilihat dari nilai Path Coefficients dan T-Statistic dimana bila variabel memiliki nilai $T$-Statistic lebih besar dari 1,96 dinyatakan ada pengaruh positif dan signifikan. ${ }^{15}$

d. Pengaruh Variabel Langsung (Direct) dan Tidak Langsung (Indirect)

Variabel Direct dan variabel indirect menyatakan besarnya pengaruh langsung dan tidak langsung variable-variabel terhadap kualitas hidup lansia penderita DM tipe 2.

\section{Hasil}

Hasil penelitian tentang karakteristik responden yaitu semua responden adalah lansia yang paling banyak berumur $60-74$ berjumlah 69 orang sebanyak $73 \%$. Selain itu pendidikan terbanyak adalah tingkat SLTA/sederajat dengan jumlah 40 responden sebesar $42,6 \%$, jenis kelamin responden terbanyak adalah wanita berjumlah 60 responden sebesar $63,8 \%$, sedangkan status perkawinan yang terbanyak adalah menikah berjumlah 90 responden atau $95,7 \%$.

Hasil gambaran tentang tanggapan responden mengenai variabel-variabel penelitian adalah jawaban minimal terdapat pada variabel fungsi keluarga yaitu dengan nilai 30 , dan yang mempunyai nilai terbesar adalah pada variabel kualitas hidup lansia dan yaitu dengan nilai 88 . Sedangkan nilai rata-rata terendah terdapat pada variabel motivasi diri 
dengan nilai 61,27 , dan nilai rata-rata tertinggi terdapat pada variabel kualitas hidup lansia dengan nilai 77,35. Nilai median terendah adalah pada variabel peran petugas kesehatan, sedangkan nilai median tertinggi terdapat pada variabel kualitas hidup lansia dengan nilai 78 . Untuk nilai mode, nilai terendah ada pada variabel peran petugas kesehatan dengan nilai 63, sedangkan pada variabel kualitas hidup lansia yang mempunyai nilai mode tertinggi yaitu dengan nilai 80 .

Hasil data mengenai kisaran jawaban responden juga dinyatakan dalam beberapa kategori dengan perhitungan nilai mean (ratarata), range (kisaran) dan standar deviasi (penyimpangan). Pada variabel Peran Petugas Kesehatan, kisaran jawaban responden antara (33-74) mendekati kisaran teoritisnya (15-75) dengan nilai rata-rata 53,5 dan standar deviasi 10,45. Hal ini mengindikasikan bahwa responden cenderung menganggap penting peran petugas kesehatan Puskesmas Ciracas. Pada variabel fungsi keluarga, kisaran jawaban responden (30-71) mendekati kisaran teoritisnya (15-75) dengan nilai rata-rata 50,5 dan standar deviasi 10.99. Hal ini mengindikasikan persepsi responden cenderung mengganggap penting fungsi keluarga. Pada variabel motivasi diri kisaran jawaban responden antara (32-71) mendekati kisaran teoritisnya pada nilai tertinggi (15-75) dengan nilai rata-rata 62,36 dan standar deviasi 10,72. Hal ini mengindikasikan persepsi responden cenderung mengganggap penting variabel motivasi diri dari penderita itu sendiri. Pada variabel gaya hidup kisaran jawaban responden antara (39-74) mendekati kisaran teoritisnya (15-75) dengan nilai rata-rata 53 dan standar deviasi 9,11. Hal ini mengindikasikan bahwa responden cenderung mengangap penting gaya hidup. Dan pada variabel kualitas hidup lansia kisaran jawaban responden dengan nilai antara (64-88) mendekati kisaran teoritisnya (24-120) dengan nilai rata-rata 69 dan standar deviasi 5,27. Hal ini mengindikasikan bahwa responden cenderung mengangap penting kualitas hidup lansia pada penderita DM tipe 2 .

Berdasarkan gambar 1 dapat terlihat bahwa nilai faktor loading telah memenuhi persyaratan yaitu nilai loading factors diatas 0,5. Suatu indikator reflektif dapat dinyatakan valid jika mempunyai loading factor diatas 0,5 terhadap konstruk yang dituju berdasarkan pada substantive content-nya dengan melihat signifikansi dari weight $(\mathrm{t}=1,96) .{ }^{15}$

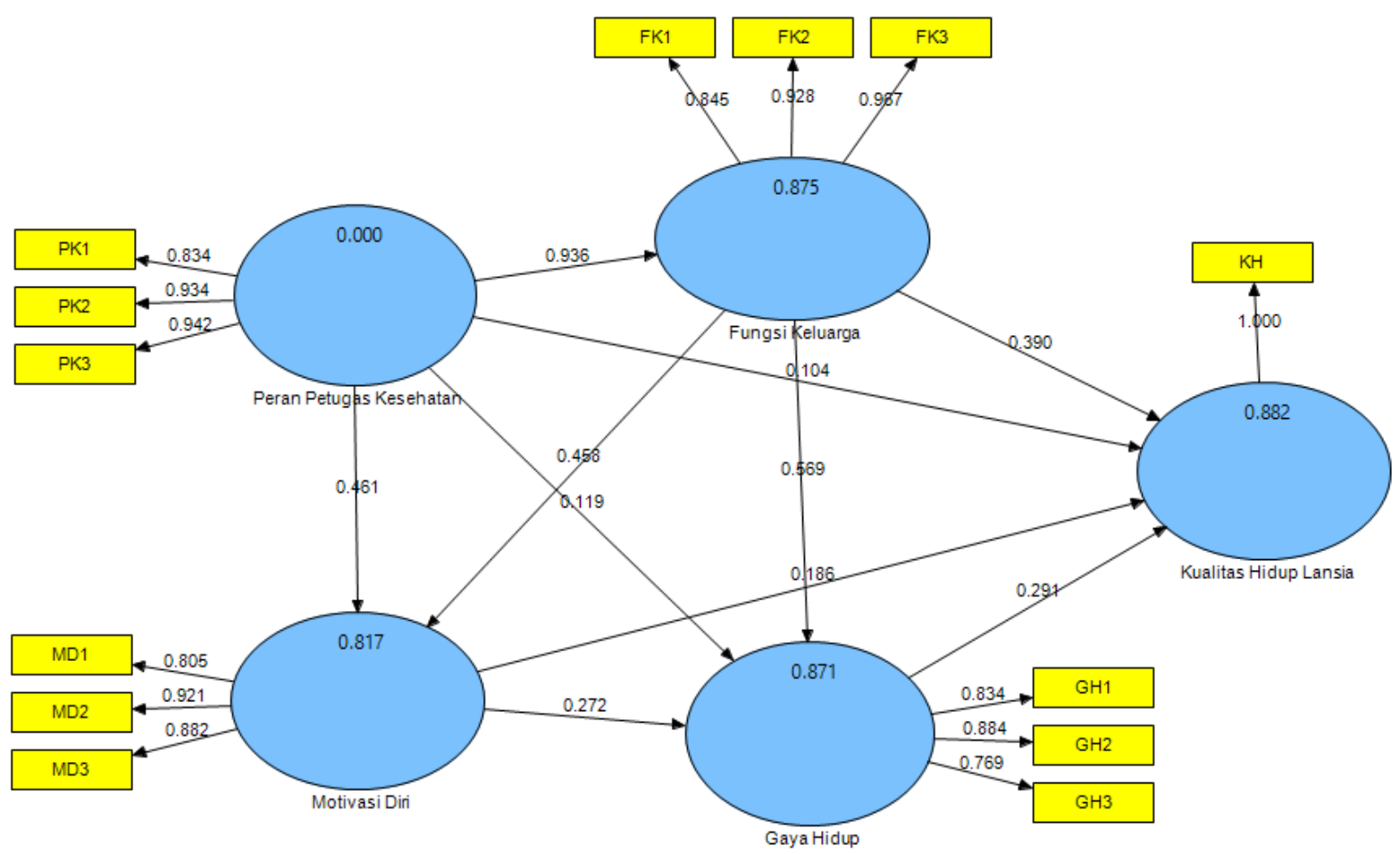

Gambar 1. Output PLS (Loading Factors)

Berdasarkan gambar 1 dapat terlihat bahwa konstruk yang digunakan untuk membentuk sebuah model penelitian, pada proses analisis faktor konfirmatori telah memenuhi kriteria dengan nilai diatas batas 
signifikansi yaitu 0,05. Gambar 1 juga dapat memperlihatkan bahwa setiap indikator atau dimensi pembentuk variabel laten menunjukkan hasil yang baik, yaitu dengan nilai loading factor yang tinggi dimana masing-masing indikator lebih besar dari 0,5. Dengan hasil tersebut bahwa pada indikator pembentuk variabel laten konstruk peran petugas kesehatan, fungsi keluarga, motivasi diri, gaya hidup dan kualitas hidup lansia penderita DM tipe 2 sudah menunjukkan hasil yang baik.

Hasil uji validitas untuk masingmasing variabel dengan mengevaluasi nilai AVE sebagai berikut : fungsi keluarga 0,84 , gaya hidup 0,69 , motivasi diri 0,76 , peran petugas kesehatan 0,82 , kualitas hidup lansia 1,0. Dapat dilihat nilai semua variabel dapat dinyatakan valid karena memberikan nilai AVE diatas 0,5. Sehingga dapat disimpulkan bahwa evaluasi pengukuran model memiliki diskriminan validity yang baik atau valid. Setelah dilakukan uji validitas dan telah dinyatakan valid variabel dan indikatornya untuk selanjutnya dilakukan uji reliabilitas. Uji reliabilitas ini dilakukan dengan melihat nilai outer model Cronbach's Alpha dan composite reliability. Nilai Cronbach's Alpha variabel fungsi keluarga 0,90 , gaya hidup 0,78 , motivasi diri 0,84 , peran petugas kesehatan 0,89 dan kualitas hidup lansia 1,00. Dengan demikian semua variabel memiliki nilai diatas 0,70 , sehingga dapat dikatakan bahwa kontruk memiliki reliabilitas yang baik.

Tabel 1. Evaluasi nilai $\mathrm{R}$ Square Model Pengaruh Peran Petugas Kesehatan,Fungsi Keluarga, Motivasi Diri, Gaya Hidup dan Kualitas Hidup Lansia Diabetes Melitus Tipe 2

\begin{tabular}{lc}
\hline Variabel & R Square \\
\hline Fungsi Keluarga & 0,88 \\
Gaya Hidup & 0,87 \\
Kualitas Hidup Lansia & 0,88 \\
Motivasi Diri & 0,82 \\
Peran Petugas Kesehatan & \\
\hline
\end{tabular}

Sumber: SmartPLS 2.0 report, 2017

Gambar 2 menyatakan nilai T-statistic direfleksikan terhadap variabelnya sebagian besar > 1,96, sehingga menunjukkan blok indikator berpengaruh positif dan signifikan untuk merefleksikan variabelnya.

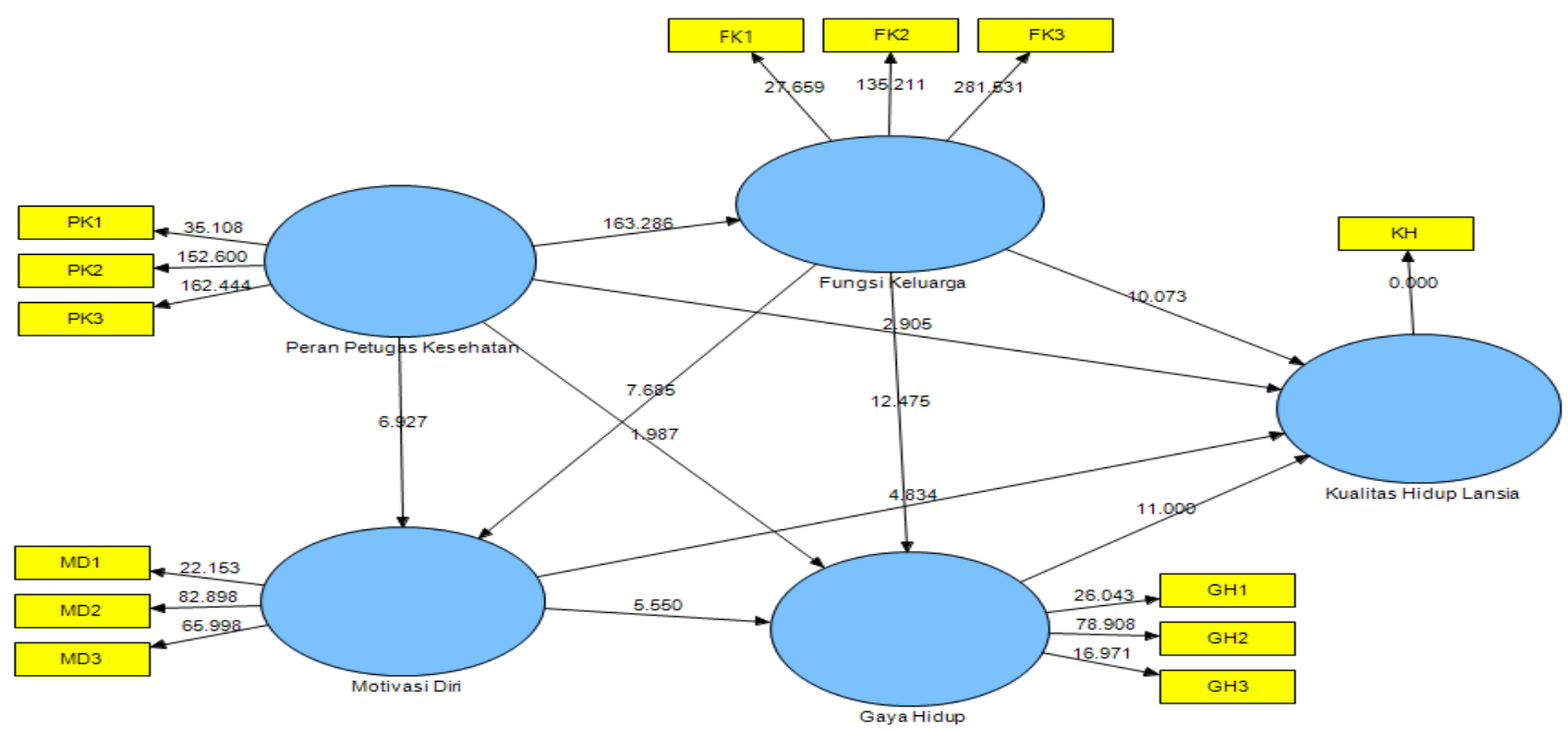

Gambar 2.Inner Model (T-Statistic) 
Tabel 2. Hasil Pengukuran Path Coefficients dan T Statistiknya Hubungan antar variabel pada Structural Model

\begin{tabular}{|c|c|c|c|c|}
\hline $\begin{array}{c}\text { Hubungan Antar } \\
\text { Variabel }\end{array}$ & $\begin{array}{c}\text { Original } \\
\text { Sampel (Rho) }\end{array}$ & $\begin{array}{l}\text { Nilai T } \\
(>1,96)\end{array}$ & $\mathbf{H}_{\mathbf{0}}$ & Kesimpulan \\
\hline $\begin{array}{l}\text { Fungsi Keluarga } \rightarrow \\
\text { Gaya Hidup }\end{array}$ & 0,57 & 12,48 & Ditolak & $\begin{array}{c}\text { Ada pengaruh Positif dan } \\
\text { Signifikan }\end{array}$ \\
\hline $\begin{array}{l}\text { Fungsi Keluarga } \\
\rightarrow \text { Kualitas hidup Lansia }\end{array}$ & 0,39 & 10,07 & Ditolak & $\begin{array}{l}\text { Ada pengaruh Positif dan } \\
\text { Signifikan }\end{array}$ \\
\hline $\begin{array}{l}\text { Fungsi Keluarga } \rightarrow \\
\text { Motivasi Diri }\end{array}$ & 0,45 & 7,69 & Ditolak & $\begin{array}{c}\text { Ada pengaruh Positif dan } \\
\text { Signifikan }\end{array}$ \\
\hline $\begin{array}{l}\text { Gaya Hidup } \rightarrow \text { Kualitas } \\
\text { Hidup Lansia }\end{array}$ & 0,29 & 10,99 & Ditolak & $\begin{array}{c}\text { Ada pengaruh Positif dan } \\
\text { Signifikan }\end{array}$ \\
\hline $\begin{array}{l}\text { Motivasi Diri } \rightarrow \text { Gaya } \\
\text { Hidup }\end{array}$ & 0,27 & 5,55 & Ditolak & $\begin{array}{c}\text { Ada pengaruh Positif dan } \\
\text { Signifikan }\end{array}$ \\
\hline $\begin{array}{l}\text { Motivasi Diri } \rightarrow \text { Kualitas } \\
\text { Hidup Lansia }\end{array}$ & 0,18 & 4,83 & Ditolak & $\begin{array}{c}\text { Ada pengaruh Positif dan } \\
\text { Signifikan }\end{array}$ \\
\hline $\begin{array}{l}\text { Peran Petugas Kesehatan } \\
\rightarrow \text { Fungsi Keluarga }\end{array}$ & 0,93 & 163,29 & Ditolak & $\begin{array}{c}\text { Ada pengaruh Positif dan } \\
\text { Signifikan }\end{array}$ \\
\hline $\begin{array}{l}\text { Peran Petugas Kesehatan } \\
\rightarrow \text { Gaya Hidup }\end{array}$ & 0,11 & 1,99 & Ditolak & $\begin{array}{l}\text { Ada pengaruh Positif dan } \\
\text { Signifikan }\end{array}$ \\
\hline $\begin{array}{l}\text { Peran Petugas Kesehatan } \\
\rightarrow \text { Kualitas Hidup Lansia }\end{array}$ & 0,10 & 2,91 & Ditolak & $\begin{array}{c}\text { Ada pengaruh Positif dan } \\
\text { Signifikan }\end{array}$ \\
\hline $\begin{array}{l}\text { Peran Petugas Kesehatan } \\
\rightarrow \text { Motivasi Diri }\end{array}$ & 0,46 & 6,93 & Ditolak & $\begin{array}{c}\text { Ada pengaruh Positif dan } \\
\text { Signifikan }\end{array}$ \\
\hline
\end{tabular}

Sumber: Diolah dari SmartPLS 2.0 report, 2017

Tabel 2 memperlihatkan bahwa semua variabel memiliki nilai $\mathrm{T}$-statistic lebih besar dari $1,96 \%$ yaitu variabel fungsi keluarga terhadap gaya hidup 12,48, fungsi keluarga terhadap kualitas hidup lansia 10,07, fungsi keluarga terhadap motivasi diri 7,69 , gaya hidup terhadap kualitas hidup lansia 10,99, motivasi diri terhadap gaya hidup 5,55, motivasi diri terhadap kualitas hidup lansia
4,83 , peran petugas kesehatan terhadap fungsi keluarga 163,29, peran petugas kesehatan terhadap gaya hidup 1,99 , peran petugas kesehatan terhadap kualitas hidup lansia 2,91, peran petugas kesehatan terhadap motivasi diri 6,93, sehingga $\mathrm{H} 0$ ditolak karena nilai $\mathrm{T}$ statistic tersebut berada jauh diatas nilai kritis $(1,96)$ sehingga signifikan pada $\alpha 5 \%$.

Tabel 3. Persentase Pengaruh Antar Variabel Terhadap Variabel

Kualitas Hidup Lansia

\begin{tabular}{lccccccc}
\hline \multicolumn{1}{c}{ Sumber } & $\begin{array}{c}\text { Correlation } \\
\text { Peran Petugas }\end{array}$ & $\begin{array}{c}\text { Direct } \\
\text { Path }\end{array}$ & $\begin{array}{c}\text { Indirect } \\
\text { Path }\end{array}$ & Total & $\begin{array}{c}\text { Direct } \\
\mathbf{\%}\end{array}$ & $\begin{array}{c}\text { Indirect } \\
\mathbf{\%}\end{array}$ & $\begin{array}{c}\text { Total } \\
\mathbf{\%}\end{array}$ \\
$\begin{array}{l}\text { Kesehatan } \\
\text { Fungsi Keluarga }\end{array}$ & 0,89 & 0,46 & 0,77 & 0,88 & 9,33 & 1,65 & 43,71 \\
Motivasi Diri & 0,92 & 0,39 & 0,29 & 0,68 & 35,97 & 0,76 & 42,95 \\
Gaya Hidup & 0,88 & 0,18 & 0,05 & 0,24 & 16,47 & 0,23 & 24,14 \\
\hline & 0,91 & 0,29 & & 0,29 & 26,43 & & 26,43 \\
\hline
\end{tabular}

Sumber: Diolah dari SmartPLS 2.0 report, 2017

Tabel 3 menyatakan besarnya pengaruh langsung dan tidak langsung variabel-variabel terhadap kualitas hidup lansia penderita DM tipe 2. Hasil uji koefisien 
parameter antara peran petugas kesehatan terhadap kualitas hidup lansia menunjukkan terdapat pengaruh langsung sebesar 9,33\%, fungsi keluarga terhadap kualitas hidup lansia menunjukkan terdapat pengaruh langsung sebesar 35,97\%, motivasi diri terhadap kualitas hidup lansia menujukan terdapat pengaruh langsung sebesar $16,47 \%$ dan gaya hidup terhadap kualitas hidup lansia menujukan terdapat pengaruh langsung sebesar 26,43\%. Sedangkan untuk pengaruh tidak langsung antara peran petugas kesehatan terhadap kualitas hidup lansia menunjukkan terdapat pengaruh langsung sebesar $1,65 \%$, fungsi keluarga terhadap kualitas hidup lansia menunjukkan terdapat pengaruh langsung sebesar $0,76 \%$, motivasi diri terhadap kualitas hidup lansia menujukan terdapat pengaruh langsung sebesar $0,23 \%$.

Secara matematis bentuk persamaan struktural dari model penelitian ini adalah sebagai berikut :

a. $\eta 1=\xi 1 \gamma 1+\eta_{3} \beta 3+\zeta 1$

Motivasi diri $=0,46$ peran petugas kesehatan $+0,46$ fungsi keluarga $+0,18$ faktor lain.

b. $\quad \eta 2=\xi 1 \gamma 2+\eta 1 . \beta 1+\eta_{3 .} . \beta 6+{ }_{\zeta 2}$

Gaya hidup $=0,12$ peran petugas kesehatan $+0,27$ motivasi diri $+0,57$ fungsi keluarga $+0,13$ faktor lain.

c. $\eta 3=\xi_{1} \gamma 3+\zeta 3$

Fungsi keluarga $=0,94$ peran petugas kesehatan $+0,13$ faktor lain.

d. $\eta 4=\xi_{1} \gamma 4+\eta 3 . \beta 5+\eta 1 . \beta 4+\eta 2 . \beta 2+\zeta 4$

Kualitas hidup lansia $=0,10$ peran petugas kesehatan $+0,39$ fungsi keluarga $+0,186$ motivasi diri $+0,29$ gaya hidup $+0,12$ faktor lain.

Nilai Q-Square berfungsi untuk menilai besaran keragaman atau variasi data penelitian terhadap fenomena yang sedang dikaji dan hasilnya sebagai berikut:

$$
\begin{aligned}
\mathrm{Q}^{2} & =1-\left(1-\mathrm{R}_{1}{ }^{2}\right)\left(1-\mathrm{R}_{2}{ }^{2}\right)\left(1-\mathrm{R}_{3}{ }^{2}\right)\left(1-\mathrm{R}_{3}{ }^{2}\right)\left(1-\mathrm{R}_{4}{ }^{2}\right) \\
& =1-(1-0,766)(1-0,668)(1-0,759)(1-0,778) \\
& =0,99 \text { atau } 99,97 \%
\end{aligned}
$$

Galat Model $=100 \%-99,97 \%=0,03 \%$

Hasil tersebut menunjukkan model hasil analisis yang dapat menjelaskan $99,97 \%$ keragaman data dan mampu mengkaji fenomena yang dipakai dalam penelitian, sedangkan $0,03 \%$ menjelaskan komponen lain yang tidak terdapat dalam penelitian ini.

Hasil pengukuran path coefficients dan T-statistic hubungan antar variabel pada structural model memperlihatkan bahwa semua variabel memiliki nilai T-statistic lebih besar dari $1,96 \%$ yaitu variabel fungsi keluarga terhadap gaya hidup 12,47, fungsi keluarga terhadap kualitas hidup lansia 10,07, fungsi keluarga terhadap motivasi diri 7,68 , gaya hidup terhadap kualitas hidup lansia 10,99, motivasi diri terhadap gaya hidup 5,54, motivasi diri terhadap kualitas hidup lansia 4,83 , peran petugas kesehatan terhadap fungsi keluarga 163,28, peran petugas kesehatan terhadap gaya hidup 1,98 , peran petugas kesehatan terhadap kualitas hidup lansia 2,90, peran petugas kesehatan terhadap motivasi diri 6,92, sehingga H0 ditolak karena nilai Tstatistic tersebut berada jauh diatas nilai kritis $(1,96)$ sehingga signifikan pada $\alpha 5 \%$.

\section{Pembahasan}

\section{Pengaruh Peran Petugas Kesehatan Terhadap Kualitas Hidup Lansia Penderita DM Tipe 2}

Hasil uji terhadap koefisien parameter antara peran petugas kesehatan terhadap kualitas hidup lansia penderita DM tipe 2 menunjukkan terdapat pengaruh langsung sebesar 9,33\%, sedangkan untuk pengaruh tidak langsung peran petugas kesehatan terhadap kualitas hidup lansia penderita DM tipe 2 melalui fungsi keluarga, motivasi diri dan gaya hidup sebesar $2,59 \%$. Nilai TStatistic sebesar 2,905 dan signifikan pada $\alpha=5 \%$. Nilai T-Statistic tersebut berada jauh diatas nilai kritis $(1,96)$.

Maka dari itu berdasarkan hasil uji tersebut dapat dijelaskan bahwa pengaruh langsung peran petugas kesehatan lebih besar nilainya dibandingkan dengan pengaruh tidak langsung dan signifikan, kemudian ada pengaruh yang positif dari kedua variabel tersebut. Nilai T-Statistic menunjukkan, bahwa ada pengaruh langsung dan tidak langsung antara peran petugas kesehatan terhadap kualitas hidup lansia penderita DM tipe 2.

Indikator peran petugas kesehatan memiliki nilai yang cukup tinggi dibandingkan dengan indikator-indikator pada variabel yang lain. Nilai indikator peran petugas kesehatan 
sebagai konselor memiliki tingkat signifikan yang paling tinggi dibandingkan indikator lainya pada peran petugas kesehatan, sehingga patut mendapatkan intervensi sesuai harapan lansia untuk meningkatkan kualitas hidup lansia penderita DM tipe 2. Hal ini sejalan dengan penelitian sebelumnya di Taiwan menyatakan bahwa peran petugas kesehatan sebagai perawatan pemberdayaan adalah prediktor yang paling penting dari kualitas hidup. ${ }^{16}$

Peran petugas kesehatan adalah suatu kegiatan yang diharapkan dari seorang petugas kesehatan yang memberikan pelayanan kesehatan kepada masyarakat untuk meningkatkan derajat kesehatan masyarakat. ${ }^{17}$ Peran petugas kesehatan dapat dideskripsikan sebagai informasi atau nasehat verbal maupun non verbal, bantuan nyata atau tindakan yang didapatkan karena kehadiran petugas kesehatan dan mempunyai manfaat emosional atau efek perilaku bagi pihak penerima, khususnya yang berhubungan dengan kesehatan raction with other people". ${ }^{18}$

Menurut asumsi peneliti petugas kesehatan harus dapat berperan sebagai edukator, screener dan konselor bagi klien untuk mencapai derajat kesehatan yang optimal. Peran petugas kesehatan sebagai konselor merupakan tempat bertanya bagi masyarakat untuk memecahkan masalah kesehatan. Petugas kesehatan harus membuka layanan konsultasi, membentuk kelompok kerja di fasilitas kesehatan dan menyediakan fasilitas seperti pemeriksaan gula darah, tandatanda vital bagi penderita DM tipe 2.

\section{Pengaruh Fungsi Keluarga Terhadap Kualitas Hidup Lansia Penderita DM Tipe 2}

Hasil uji terhadap koefisien parameter antara fungsi keluarga terhadap kualitas hidup lansia penderita DM tipe 2 di Puskesmas Ciracas menunjukkan terdapat pengaruh langsung sebesar $35,97 \%$, sedangkan untuk pengaruh tidak langsung fungsi keluarga terhadap kualitas hidup lansia penderita DM tipe 2 melalui motivasi diri sebesar $0,81 \%$. Nilai T-statistic sebesar 21,57 dan signifikan pada $\alpha=5 \%$. Nilai T-statistic tersebut berada jauh diatas nilai kritis $(1,96)$.

Maka dari itu berdasarkan hasil uji tersebut dapat dijelaskan bahwa pengaruh langsung fungsi keluarga lebih besar nilainya dibandingkan dengan pengaruh tidak langsung dan signifikan serta ada pengaruh yang positif dari kedua variabel tersebut. Nilai T-statistic menunjukan, bahwa ada pengaruh langsung

dan tidak langsung antara fungsi keluarga terhadap kualitas hidup lansia penderita DM tipe 2 .

Hasil penelitian tersebut menunjukkan, terdapat pengaruh yang positif dari fungsi keluarga terhadap kualitas hidup lansia penderita DM tipe 2. Hasil penelitian ini juga sejalan dengan penelitian sebelumnya dengan menggunakan SmartPLS 2,0 output hasilnya menyatakan fungsi keluarga mendapatkan nilai T-statistic 2,81>1,96 yang artinya fungsi keluarga mempunyai pengaruh positif dan signifikan terhadap kualitas hidup. ${ }^{19}$

Fungsi keluarga apabila ditingkatkan maka akan dapat meningkatkan pula kualitas hidup lansia pada penderita diabetes mellitus yang lebih baik, secara langsung maupun secara tidak langsung melalui motivasi diri dan gaya hidup, begitu juga sebaliknya apabila fungsi keluarga menurun atau tidak diperhatikan dapat menurunkan kualitas hidup lansia penderita DM tipe 2 secara langsung dan tidak langsung. Indikator perawatan kesehatan memiliki tingkat signifikan yang paling tinggi dibandingkan indikator lainya pada fungsi keluarga, sehingga sangat perlu mendapatkan intervensi sesuai harapan lansia untuk meningkatkan motivasi keluarga terhadap kualitas hidup lansia penderita DM tipe 2.

Berdasarkan indikator yang diukur pada variabel fungsi keluarga, semua indikator rmampu menjelaskan variabel fungsi keluarga yaitu fungsi perhatian dan kasih sayang, sosialisasi serta perawatan kesehatan, hal ini membuktikan teori bahwa peningkatan kesehatan dapat dianggap berperan penting dalam fungsi keluarga untuk memperbaiki fungsi total dari anggota keluarga sehingga didapatkan kualitas hidup yang baik dalam setiap anggota keluarganya. ${ }^{20}$

Keluarga memegang peranan terbesar dan terlama dalam pembentukan sikap dan perilaku individu. Hal ini karena pola asuh orang tua akan membentuk kebiasaan anak yang secara tidak langsung mempengaruhi pola hidupnya. ${ }^{21}$ Keluarga merupakan konteks sosial primer untuk promosi kesehatan dan pencegahan penyakit. Kepercayaan nilai dan praktik dalam keluarga sangat mempengaruhi tingkah laku promotif bagi kesehatan anggotanya. Dengan hal ini status kesehatan keluarga akan mempengaruhi fungsi unit 
keluarga dan kemampuannya memcapai tujuan. Jika mereka dapat berfungsi dan memenuhi tujuannya dengan memuaskan, anggota keluarga akan berfikir positif mengenai dirinya dan keluarganya, sebaliknya jika kebutuhan tidak terpenuhi, keluarga akan memandang dirinya sebagai keluarga yang tidak efektif. ${ }^{22}$

Di zaman modern seperti sekarang ini, peran keluarga sangat penting bagi tercapainya kualitas hidup lansia, apalagi kondisi fisik lansia yang semakin bertambahnya usia maka semakin menurun kondisi fisiknya, sehingga diperlukan dukungan keluarga dalam memenuhi kebutuhan hidup dan mempertahankan derajat kesehatan. Peran anggota keluarga terhadap lansia sebagai upaya rehabilitatif dan kuratif antaralain: membantu mencukupi kebutuhannya, membantu memenuhi sumber-sumber keuangan, mengupayakan sarana transportasi untuk kegiatan mereka termasuk rekreasi, dll. ${ }^{23}$

Menurut analisa peneliti keluarga merupakan satu unit kesatuan yang tidak terpisahkan. Lansia dengan penderita Diabetes Melitus di wilayah Puskesmas Ciracas lebih banyak tinggal dengan keluarganya dan mendapatkan perawatan, perhatian dan kasih sayang langsung dari keluarga. Oleh karena itu fungsi keluarga memiliki pengaruh positif terhadap kualitas hidup lansia pederita DM tipe 2.

\section{Pengaruh Motivasi Diri Terhadap Kualitas Hidup Lansia Penderita DM Tipe 2}

Hasil uji terhadap koefisien parameter antara motivasi diri terhadap kualitas hidup lansia penderita DM tipe 2 menunjukkan terdapat pengaruh langsung sebesar $16,47 \%$, sedangkan untuk pengaruh tidak langsung motivasi diri terhadap kualitas hidup lansia penderita DM tipe 2 melalui gaya hidup penderita DM tipe 2 sebesar $0,09 \%$. Nilai Tstatistic sebesar 5,55 dan signifikan pada $\alpha=5 \%$. Nilai T-statistic tersebutberada jauh diatas nilai kritis $(1,96)$.

Maka berdasarkan hasil uji tersebut dapat dijelaskan bahwa pengaruh langsung motivasi diri lebih besar nilainya dibandingkan dengan pengaruh tidak langsung dan signifikan serta ada pengaruh yang positif dari kedua variabel tersebut. Nilai T-statistic menunjukkan, bahwa ada pengaruh langsung dan tidak langsung antara motivasi diri terhadap kualitas hidup lansia penderita DM tipe 2. Hasil penelitian tersebut menunjukkan, terdapat pengaruh yang positif dari motivasi diri terhadap kualitas hidup lansia penderita DM tipe 2. Apabila motivasi diri tinggi maka kualitas hidup lansia akan berubah. Hal ini sejalan dengan teori yang menyatakan bahwa seberapa kuat motivasi diri yang dimiliki individu akan banyak menentukan terhadap kualitas hidupnya. ${ }^{24}$

Berdasarkan indikator yang diukur pada variabel motivasi diri, semua indikator rmampu menjelaskan variabel motivasi diri yaitu kebutuhan, tujuan dan harapan. Dari ketiga indikator tersebut yang memiliki nilai paling tinggi adalah indikator tujuan. Hal ini membuktikan pendapat menurut Robbins sangat tepat, yang mengatakan motivasi adalah kejelasan proses dalam intensitas, arah dan ketekunan pada usaha mencapai tujuan. ${ }^{25}$

Menurut asumsi peneliti motivasi diri dapat merubah prilaku seseorang. Lansia penderita diabetes mellitus di wilayah Puskesmas Ciracas memiliki motivasi diri untuk sembuh yang cukup tinggi. Hal ini dapat dilihat pada jadwal control yang rutin dilakukan. Dengan demikian motivasi diri lansia penderita diabetes mellitus di Ciracas dapat merubah prilaku hidup sehat sehingga meningkatkan kualitas hidup.

\section{Pengaruh Gaya Hidup Terhadap Kualitas Hidup Lansia Penderita DM Tipe 2}

Hasil uji terhadap koefisien parameter antara gaya hidup terhadap kualitas hidup lansia penderita DM tipe 2 di Puskesmas Ciracas menunjukkan terdapat pengaruh langsung sebesar $26,43 \%$, sedangkan untuk pengaruh tidak langsung gaya hidup terhadap kualitas hidup lansia penderita DM tipe 2 di Puskesmas Ciracas tidak ada yang mempengaruhinya. Gaya hidup berpengaruh positif terhadap kualitas hidup lansia penderita DM tipe 2 di Puskesmas Ciracas. Hasil uji terhadap koefisien parameter antara gaya hidup terhadap kualitas hidup lansia penderita DM tipe 2 di Puskesmas Ciracas menunjukkan ada pengaruh positif, dan nilai T-statistic signifikan sebesar 10,99 pada $\alpha=5 \%$. Nilai Tstatistic tersebut berada jauh diatas nilai kritis $(1,96)$. Hasil penelitian tersebut menunjukkan, terdapat pengaruh langsung yang positif dari gaya hidup terhadap kualitas hidup lansia 
penderita DM tipe 2. Apabila gaya hidup baik maka kualitas hidup lansia akan berubah baik pula.

Hasil penelitian ini sejalan dengan penelitian di Iran yang menyatakan bahwa ada hubungan langsung antara gaya hidup dan kualitas hidup. Skor rata-rata (mean) kualitas hidup adalah 69,06 \pm 20,97 (kisaran 0-100) dan nilai rata-rata (mean) dari gaya hidup adalah 161,91 $\pm 13,95$ (kisaran 42-211) ${ }^{10}$ Penelitian lain juga menunjukan bahwa gaya hidup berpengaruh positif terhadap kualitas hidup lansia. Hasil uji terhadap koefisien parameter antara gaya hidup terhadap kualitas hidup lansia menunjukkan ada pengaruh positif 0,59, sedangkan nilai T-statistic sebesar 25,49 dan signifikan pada $\alpha=5 \%$. Nilai T-statistic tersebut berada jauh diatas nilai kritis $(1,96)^{18}$

Memiliki gaya hidup yang sehat memiliki keuntungan akan merasa tentram, aman dan nyaman, memiliki rasa percaya diri, hidup seimbang, tidur nyenyak, penampilan lebih sehat dan ceria, bisa lebih sukses dalam pekerjaan, bisa menikmati kehidupan sosial di lingkungan keluarga, saudara dan tetangga. ${ }^{26}$

Menurut analisa peneliti gaya hidup lansia penderita diabetes mellitus tipe $2 \mathrm{di}$ wilayah Puskesmas Ciracas rutin meluangkan waktunya dipagi hari untuk melakukan aktifitas olahraga ringan. Selain itu mereka juga mampu menjaga konsumsi makanan rendah gula. Dengan rutin melakukan aktifitas olahraga dan menjaga pola konsumsi dapat menjaga status kesehatan sehingga meningkatkan kualitas hidup lansia.

\section{Kesimpulan}

Hasil penelitian ini menyimpulkan bahwa terdapat pengaruh langsung antara peran petugas kesehatan, fungsi keluarga, motivasi diri dan gaya hidup terhadap kualitas hidup lansia dengan DM tipe 2 di Puskesmas Ciracas. Peran petugas kesehatan dan fungsi keluarga dari lansia dengan DM tipe 2 merupakan faktor yang dominan yang sangat mempengaruhi kualitas hidup lansia dengan DM tipe 2 di Puskesmas Ciracas.

Saran dalam penelitian ini adalah: 1) Instansi Puskesmas sebaiknya dapat mempertahankan dan meningkatkan peran petugas kesehatan dalam kegiatan konsultasi terhadap lansia penderita DM tipe 2 sehingga dapat mendeteksi kualitas hidup lansia diawal yang akan mempengaruhi intervensi yang akan diberikan. 2). Keluarga sebaiknya dapat meningkatkan fungsi keluarga agar lansia memiliki kualitas hidup yang baik, dengan cara lebih memperhatikan kebutuhan dan meningkatkan kasih sayang pada lansia.

\section{Daftar Pustaka}

1. Pusat data dan informasi Kemenkes. Situasi Lanjut Usia (Lansia) Di Indonesia. Kemenkes: Infodatin; 2016.

2. Balitbangkes Kemekes RI. Riset kesehatan dasar. RISKESDAS. Jakarta: Kemenkes RI; 2013.

3. Dewi, Rifka Kumala. Diabetes bukan untuk ditakuti. Jakarta: FMedia; 2014.

4. Indriani, Ririn. WHO: Penderita diabetes di dunia capai 422 juta orang. Diakses dari http://www.suara.com/health/2016/04/07/0829 12/who-422-juta-orang-dewasa-menderitadiabetes. (7 April 2016)

5. Hanum Atiqa. Jumlah penderita diabetes Indonesia Peringkat ke-7 di Dunia; 2016 Diakses http://www.harianjogja.com/baca /2016/08/31/jumlah-penderita-diabetesindonesia-peringkat-ke-7-di-dunia-749111 (31 Agustus 2016).

6. Rafikasari Diana. Penderita diabetes di Indonesia ke tujuh terbesar di dunia; 2014. Diakses dari http://lifestyle.sindonews.com /read/ 1101939/155/ penderita-diabetes-diindonesia-ketujuh-terbesar-di-dunia1460963840.(18 April 2016).

7. Pradono J, Hapsari D, dan Sari P, Classification of functioning, disability and health (ICF) dan faktor-faktor yang mempengaruhinya. (analisis lanjut data riskesdas 2007). Bul. Penelit. Kesehat., Supplement 2009

8. Sutikno, E. Hubungan fungsi keluarga dengan kualitas hidup lansia (Doctoral dissertation, Universitas Sebelas Maret); 2011.

9. Kusmaedi, N. Pembelajaran gaya hidup sehat menuju tingkat sehat prima terpadu sepanjang hayat. Jurnal Cakrawala Pendidikan, 5(2) ; 2013.

10. Rezaeipandari, et al. Relationship between lifestyle and quality of life in older adults Yazd City, Iran. Diakses dari Elderly Health Journal 2015;1(2): 91-97 . Shahid Sadoughi University of Medical Sciences, Yazd, Iran. Journal Website : http://ehj.ssu.ac.ir

11. Ferrand, C., Martinent, G., Bonnefoy, M. Exploring motivation for exercise and its relationship with health-related quality of life in adults aged 70 years and older. Jurnal Cambridge University Press. Ageing and Society / FirstView Article / October 2012, pp 117 DOI: 10.1017/S0144686X12001092

12. Notoatmodjo. Buku ajar fundamental keperawatan. Jakarta : Salemba Medika; 2012. 
13. Kinasih, K. D, dkk. Peran pendampingan spiritual terhadap motivasi kesembuhan pada pasien lanjut usia. Diakses dari Jurnal STIKES Volume 5, No.1, Juli 2012

14. Hastono, Sutanto P. Analisis data kesehatan. Depok: FKM UI; 2007.

15. Latan H. Structural equation modeling konsep dan aplikasi menggunakan program SmartPLS 2.0. Bandung: Alfabeta; 2012.

16. YCTu, RHWang, SHYeh. Relationship between perceived empowerment care and quality of life among elderly residents within nursing homes in Taiwan: a questionnaire survey.Int J Nurs Stud. 2006 Aug;43(6):67380. Epub 2005 Nov 28
17. Setiadi. Keperawatan keluarga. Jakarta : EGC; 2008.

18. Trismiati. Psikologi keperawatan dan kecemasan. Jakarta: EGC; 2006.

19. Novianti K. Pengaruh fungsi keluarga dan gaya hidup terhadap kualitas hidup pada lansia di puskesmas tegal gundil bogor utara. Thesis. Jakarta: FKM Sekolah Tinggi Ilmu Kesehatan Indonesia Maju; 2014. 